\title{
A VOZ DE POLONO-BRASILEIROS: UM CONTEXTO HISTÓRICO SUL PARANAENSE
}

\author{
THE VOICE OF POLISH-BRAZILIANS: \\ A HISTORICAL CONTEXT IN SOUTHERN PARANÁ
}

Ivelã Pereira | Lattes | ivelpereira@gmail.com

Universidade Federal de Santa Catarina

\begin{abstract}
"Muitos têm vergonha de ser polonês, têm vergonha de sua própria língua, têm vergonha de falar em polonês. [...] eu sempre digo: o polaco é o avesso do negro."
\end{abstract}

(Polono-brasileira, Quedas do Iguaçu - PR)

Resumo: Considerando o contexto histórico de expressiva imigração polonesa no estado do Paraná, esta investigação, inicialmente, procura traçar reflexões a partir de entrevistas de polono-brasileiros do sul desse estado, com base em duas entrevistas sociolinguísticas de sujeitos nascidos e residentes na cidade de Quedas do Iguaçu - PR (antiga “Jagoda”), as quais são constituintes do banco VARLINFE (UNICENTRO - campus Irati). O polonês - língua materna de tais informantes - é considerado uma língua minoritária no Brasil, e muitos descendentes restringiram seu uso por questões históricas de interdição e silenciamento, o que desencadeou um apagamento linguístico e cultural entre muitos deles. Com isso, o objetivo principal deste artigo é depreender as dificuldades encontradas pelos sujeitos entrevistados (e antepassados) em sua inserção na sociedade brasileira, levando-se em conta as variadas esferas sociais em que interagem, bem como o(s) silenciamento(s) histórico(s) e a (não) consideração do pluralismo linguístico no Brasil. Para tanto, fundamentamo-nos em: Altenhofen (2007, 2013), Calvet (2007), Delong e Kersch (2014), Doustdar (1990), Almeida e Zanini (2011), Gardolinski (1956; 1976), Maher (2013), Nadalin (2001), Oliveira (2016), Polanczyk (2010), Wachowicz (1981, 2010), além de outros teóricos dedicados a pesquisas nas áreas de história e políticas linguísticas. A partir de uma metodologia qualitativa, foram transcritos e analisados trechos em que os informantes relatam situações de uso da língua polonesa, iniciação escolar, atividades culturais étnicas, bem como sua relação com sujeitos de outras etnias. Com base em tais depoimentos, talvez seja possível pensar estratégias de propagação do pluralismo linguístico e cultural, além de contribuir para a construção da história e a manutenção da língua desses imigrantes tão silenciados - embora tão representativos ao Paraná e ao Brasil.

Palavras-chave: Polono-brasileiros; História do Paraná; Imigração; Plurilinguismo. 
Abstract: Considering the historical context of expressive Polish immigration in Paraná, this investigation initially seeks to draw reflections on from interviews with PolishBrazilians from the south of this state. These sociolinguistic interviews are from two born and raised residents of Quedas do Iguaçu - PR (old "Jagoda"), and come from the VARLINFE database (from UNICENTRO - Irati campus). Polish - mother-tongue of the interviewees - is considered a minor language in Brazil, and many descendants have restricted their use for historical reasons of interdiction and silencing, which has triggered a linguistic and cultural erasure among many of them. Thus, the main objective of this article is to understand the difficulties by the subjects interviewed (and their ancestors) in their insertion in Brazilian society in the different social spheres in which they interact. For this, we analyze the historical silencing and the (non-)consideration of linguistic pluralism in Brazil. To do this, we based our readings on Altenhofen (2007, 2013), Calvet (2007), Delong and Kersch (2014), Doustdar (1990), Almeida and Zanini (2011), Gardolinski (2013), Nadalin (2001), Oliveira (2016), Polanczyk (2010), Wachowicz $(1981,2010)$, as well as other theorists dedicated to History and Language Policies. From a qualitative methodology, excerpts have been transcribed and analyzed in which the informants report situations of use of the Polish language, school initiation, ethnic cultural activities, as well as their relationship with subjects of other ethnic groups. Based on such interviews, it may be possible to think the strategies for the propagation of linguistic and cultural pluralism. We aim to contribute to the construction of their history and to promote the Polish language, because we believe that these silenced immigrants are so representative in Paraná and in Brazil.

Keywords: Polish-Brazilians; Paranás history; Immigration; Plurilingualism.

\section{Introdução}

Em consideração à expressiva imigração polonesa no Paraná, o tema deste artigo diz respeito à história de polono-brasileiros no sul do estado, a partir de duas ${ }^{1}$ entrevistas sociolinguísticas contemporâneas feitas para o banco VARLINFE (campus Irati) e de referenciais teóricos (das áreas de História e Políticas Linguísticas) que nos permitiram

\footnotetext{
${ }^{1}$ Foram analisadas apenas duas entrevistas, neste artigo, pelas seguintes razões: (i) até o momento em que este artigo foi escrito, tínhamos feito metade das 24 entrevistas sociolinguísticas a que nos propomos; (ii) em relação às outras entrevistas já feitas, percebemos que os informantes trataram pouco sobre silenciamento linguístico e interdições linguísticas, uma vez que muitos deles (embora descendentes étnicos) não falam mais o polonês e desconhecem a escrita dessa língua; (iii) os dois informantes escolhidos para esta pesquisa são, nitidamente, lideranças envolvidas com a propagação e manutenção da cultura polonesa no município, manifestando forte identidade polonesa.
} 
estabelecer relações entre as memórias desses sujeitos e os registros históricos referentes à imigração dessa etnia. Nesse contexto, nosso objetivo principal consistiu em analisar entrevistas com descendentes poloneses, buscando perceber as marcas que o contexto histórico de silenciamento deixou em suas histórias e memórias pessoais, assim como os reflexos desse processo de desvalorização em detrimento à sua busca pela manutenção e propagação da língua e cultura polonesas.

Esta pesquisa se justifica pelo que apontam Delong e Kersch (2014), ao mencionarem a necessidade de estudos acerca de polono-brasileiros, sendo o nosso foco a questão de políticas linguísticas de línguas minoritárias² (cf. ALTENHOFFEN, 2013; MAHER, 2013). Nesse sentido, pesquisas voltadas ao tema podem auxiliar para que o plurilinguismo seja cada vez mais valorizado no Brasil. "O conhecimento sobre as línguas minoritárias, reconhecendo-lhes o valor, desenvolverá atitudes positivas em relação a elas e, consequentemente [, diminuindo] o preconceito em relação a elas e a seus falantes” (DELONG; KERSCH, 2014, p. 85). Ademais, a análise das entrevistas, com foco no ponto de vista dos entrevistados, poderá trazer subsídios e material a outros pesquisadores que se dedicarem ao tema, objetivando um maior delineamento da história da imigração polonesa no Paraná - em valorização à sua expressividade na constituição histórica brasileira e paranaense.

Nossa fundamentação teórica revelou que existe um preconceito instituído historicamente em relação aos polacos 3 (cf. DOUSTDAR, 1990; IAROCHINSKI, 2001, 2003; BORSTEL, 2005; POLANCZYK, 2010; WOLNY, 2012), que parece acontecer de maneira ainda mais significativa do que o ocorrido contra os colonos vindos da Itália e da Alemanha, por exemplo. Mas existem raízes históricas (DOUSTDAR, 1990) para isso, sobre as quais iremos tratar em seção subsequente, que mostram como essa visão discriminatória foi se construindo ao longo do tempo.

Com base nisso e em outras questões mencionadas em seção ulterior, nossa hipótese é de que o apagamento contemporâneo da polonidade ${ }^{4}$, bem como o preconceito antipo-

\footnotetext{
2 De acordo com Altenhoffen (2013, p. 94), “a designação língua minoritária surge como um contraponto do que é majoritário e sugere um dualismo entre uma língua 'geral' e 'comum' e tudo que é exceção ou existe à margem de. [... Trata-se de uma] modalidade de línguas ou variedades usadas à margem ou ao lado de uma língua (majoritária) dominante”.

3 O termo "polaco" é comumente utilizado para se referir aos poloneses (tanto os que vivem na Polônia quando os que imigraram para o Brasil e outros países). No entanto, por questões históricas, muitos polono-brasileiros não gostam de ser assim chamados, sobretudo em relações interétnicas, como será mostrado na parte analítica deste artigo.

4 Tomamos como significado de polonidade o que afirmam Almeida e Zanini (2013, p. 163), tal como um "pertencimento ao mundo polonês, vislumbrado por meio de narrativas, símbolos e uma série de elementos" culturais envolvidos nesse sentimento de identidade polonesa. Para um maior aprofundamento sobre o tema, ver Araújo Filho (2003), Slodkowski (2013), Almeida (20110) e Almeida e Zanini (2013).
} 
lonês (DOUSTDAR, 1990), seria resultado de uma história repetitiva de silenciamento, preconceito e despolonização, cujas principais vítimas foram os próprios imigrantes poloneses e seus descendentes no Brasil.

Em oposição a esse contexto de discriminação, interdição e de mudezes forçadas, pretendemos dar voz (e vez) a esses representantes atuais da etnia polonesa no Brasil. Para que isso aconteça, argumentamos que seja necessária a implantação de políticas públicas de promoção linguísticas e culturais de tal etnia (cf. MAHER, 2013; ALTENHOFFEN, 2013; e OLIVEIRA, 2016).

A fim de se cumprir o que nos propomos, este artigo está dividido em três seções principais, sendo que a próxima tem caráter histórico e traça uma contextualização da Polônia e do Brasil no período em que ocorreu a imigração europeia (sobretudo a polonesa) para este país. A seção em sequência descreve a metodologia da pesquisa e analisa trechos das entrevistas dos informantes polono-brasileiros, permeando-os de reflexões sobre questões de identidade polônica e políticas linguísticas de línguas minoritárias (principalmente no que tange ao polonês). Por fim, as considerações finais fazem um apanhado geral da pesquisa - retomando o objetivo e a hipótese inicial - e trazem possibilidades de incentivo à promoção da língua e cultura polonesas no Paraná.

\section{Contextualização histórica}

Para se entender a questão da imigração desses indivíduos para o Brasil, é preciso primeiramente levar em conta a história da Polônia em meados do século XVIII e XIX. "A Polônia, como nação livre e independente, desapareceu em fins do século XVIII, tornando-se parte da periferia oriental dos grandes centros decisórios da Europa Ocidental, típica de marginalização.” (DOUSTDAR, 1990, p. 62).

Tratava-se de uma terra tripartida pelo domínio da Rússia, Prússia e Áustria (GARDOLINSKI, 1976), onde os poloneses - em sua maioria - encontravam-se em total vulnerabilidade, vivendo sob o jugo dos grandes proprietários de terras, numa relação de servidão e significativa miséria. Segundo Polanczyk (2010), a Polônia esteve organizada, durante séculos, nas seguintes categorias sociais: magnatas (ricos latifundiários), príncipes e condes, pequena nobreza, cardeal, bispos e monges, habitantes da cidade, judeus e camponeses, sendo essa última classe a mais sofrida e subserviente aos magnatas e às potências que haviam dominado o país.

É importante salientar que nesse período de partilha da Polônia, os poloneses passaram por um forte processo de despolonização sob o jugo de potências que os domina- 
vam, num processo forçado de assimilação cultural dos dominadores. "Nas três regiões, a língua polonesa foi substituída nos órgãos públicos, nas escolas e no púlpito das igrejas. Para se dirigirem às autoridades, os poloneses não podiam fazê-lo em sua própria língua, eram estrangeiros em sua terra." (POLANCZYK, 2010, p. 206). Além disso, conforme menciona Doustdar (1990), na região dominada pela Prússia, foi tentada a eliminação da cultura polonesa não só mediante a proibição do uso da língua, mas também através da substituição dos nomes de ruas, praças e cidades por nomes alemães e, principalmente, a criação da "Comissão Colonizadora Alemã" (DOUSTDAR, 1990, p. 63), que forçou os poloneses a venderem suas terras aos agricultores germânicos.

Esse ponto é essencial para que se entenda outro aspecto importante relacionado aos poloneses: a questão do germanismo antipolônico (DOUSTDAR, 1990), o qual consiste em um sentimento de discriminação dos poloneses, por parte dos alemães ${ }^{5}$, em virtude do domínio prussiano em certa região da Polônia. "Após a vitória da Prússia sobre a França, em 1870, e o surgimento do Império Alemão sob hegemonia prussiana, os territórios da Silésia, Pomerânia e Renânia, a leste do Elba, habitados por poloneses, foram objeto de notável ação de despolonização” (DOUSTDAR, 1990, p. 63). Além disso, a Comissão Colonizadora Alemã afastou os poloneses de suas propriedades rurais pressionando-os a vendê-las.

Ou seja, já naquele tempo os polônios viveram um processo intenso de silenciamento linguístico e cultural. Mas esse foi apenas um dos momentos de despolonização pelos quais passaram esses indivíduos. Também no Brasil, o polonês iria sofrer preconceito e desvalorização. Se na Europa o polonês era vítima de uma descaracterização cultural e, pelos trabalhadores alemães, visto como fator de desagregação das relações salariais, no Brasil estaria condicionado a trabalhos pesados em substituição aos mulatos e índios. "O imigrante polonês estava sendo confrontado, sempre, com as camadas inferiores da sociedade, da ótica da ideologia racial e elitista do país.” (DOUSTDAR, 1990, p. 68).

Em relação às categorias sociais, "os pesquisadores estão concordes quanto ao caráter da emigração polonesa para o Brasil entre os anos de 1890-1914 era uma emigração predominantemente de camponeses, composta de famílias cujo objetivo era possuir uma propriedade agrícola no Brasil.” (POLANCZYK, 2010, p. 200). Além disso, existia uma alta taxa de analfabetismo ${ }^{6}$ entre esses camponeses, uma vez que "as três potências

\footnotetext{
${ }^{5}$ É claro que esse tipo de discriminação não abarca todos os descendentes germânicos, mas é fato que isso pode ser observado em algumas situações de relação interétnica. Um exemplo disso é exposto em Doustdar (1990, p. 114-115) quando aparece um depoimento de um polono-brasileiro que se passava por alemão - por conta do sobrenome registrado errado e similar à escrita germânica -, mas foi descoberto por um descendente de alemão, o qual gritou: "Polnische Schwein" e cuspiu em seu rosto.

${ }^{6}$ Obviamente que isso não atingia toda a população polonesa e que imigrantes mais escolarizados vieram
} 
usurpadoras dos territórios poloneses, através dos seus representantes, não viam, nem tinham qualquer interesse no sentido de levantar ou aprimorar o nível cultural dos seus súditos" (GARDOLINSKI, 1976, p. 14), com vistas a um processo de desnacionalização em favor daqueles que dominavam as terras polonesas. Estavam os poloneses, portanto, acostumados à escravidão e à subserviência no momento em que a miséria e a vontade de ter um pedaço de terra foram tão fortes que os moveram a querer emigrar de sua pátria tripartida. De acordo com Malczewski (1998, p. 28), as causas da emigração polonesa foram: "a perda da independência do país, crescimento do perigo individual e comunitário, conflitos armados com os invasores e às vezes como consequências a necessidade de fuga diante das represálias (imigrantes políticos), como também a situação econômica difícil."

Se nesse momento que a situação do camponês polonês era sofrível pelas causas já apontadas, por outro lado surgiu a possibilidade de mudança, e o Brasil era uma dessas saídas, dotado de propagandas tentadoras. "O ‘Guia do Emigrante para o Império do Brasil', escrito em 1884 pelo inspetor geral dos assuntos da terra e colonização Accioni de Vasconcelos é o melhor exemplo desse tipo de literatura propagandista" (MALCZEWSKI, 1998, p. 28). Havia promessas de que as terras brasileiras seriam de excelente qualidade, cortadas por estradas, o que possibilitaria ao imigrante pagar sua dívida com facilidade e se tornar um absoluto senhor de sua propriedade rural. Consistiam em propagandas tentadoras ao contexto de pobreza extrema em que se encontravam os poloneses.

Segundo o historiador Nadalin (2001, p. 65), a política imigratória brasileira tinha o objetivo de "construir uma nova nação", numa política de povoamento de "vazios demográficos" - como era considerado, por exemplo, a região Oeste do Paraná - e branqueamento da população. Também se buscava imigrantes que pudessem cultivar no país as "virtudes do trabalho", característica que acreditavam não possuírem os negros e índios aqui presentes. Esse processo se iniciou com a vinda de uma leva de aproximadamente 50 mil portugueses (cf. NADALIN, 2001) no período em que se transferiu a Corte portuguesa ao Brasil, o que favoreceu as políticas de colonização com outros imigrantes europeus. Para Nadalin (2001), havia uma tendência de privilegiar a vinda de camponeses da Europa Central, o que ocorreu durante boa parte do século XIX, com o estímulo da lei de 1820. Com isso, em 1819 e o ano da Independência, houve uma contingência de quase 2.300 europeus, sendo que grande parte imigrou do centro da Europa. "Agregando os anos de 1823 a 1849, esse quantitativo saltaria para algo em torno de 22.000 imigrantes" (NADALIN, 2001, p. 65).

também para o Brasil, como mostra a obra "Perfis Polônicos no Brasil” (2000), de Wachowicz e Malczewski, a qual focaliza a "elite cultural" polonesa que se refugiou no Brasil. 
Nesse contexto histórico, o ano de 1869 é considerado o ano de início da imigração polonesa ao Brasil, cuja grande maioria era formada por agricultores que vieram em busca da terra prometida ${ }^{7}$ e de liberdade da submissão senhorial imposta pelos estrangeiros invasores da Polônia. É preciso salientar que "oficialmente os direitos senhoriais à servidão, resto do feudalismo, foram extintos na Prússia em 1807-1850; em 1848, na Áustria; em 1864, na Rússia. Mas a população camponesa não mudou seu comportamento e sua mentalidade" (POLANCZYK, 2010, p. 202). Ainda pensavam como "servos" quando emigraram de sua terra, esperando encontrar no Brasil algum tipo de liderança que pudesse protegê-los e encaminhá-los.

Não sabiam, ainda, porém, o que lhes traria a segunda pátria, a "Nova Polônia" Nowa Polska (GARDOLINSKI, 1956; MALCZEWSKI, 1998). Conforme Wachowicz (2010), ao saírem de uma Polônia arcaica e colonizada, eles carregavam consigo ressentimentos e estereótipos de sua terra de origem, o que inevitavelmente iria ressurgir na nova terra, principalmente pelo fato de terem encontrado no Brasil as mesmas nacionalidades que os oprimiam em sua terra natal (como os germânicos, por exemplo).

Apesar de as propagandas brasileiras com objetivos imigratórios serem feitas não somente aos polônios, como também a outros europeus, houve certas diferenças entre a recepção dessas etnias europeias. Esclarece Polanczyk (2010), que o governo brasileiro, para atrair alemães, ofereceu condições bastante favoráveis: viajariam às custas do governo, receberiam uma terra com 77 hectares, além de ajuda financeira e isenção de impostos. Também as zonas de colonização italianas, criadas em 1875 , foram cuidadosamente protegidas e incentivadas pelo governo do RS. Já o imigrante polonês recebeu 12,5 hectares de terra, a qual deveria pagar, e era contratado para abrir estradas em meio à mata fechada.

Mais uma vez, então, - ao se observar as diferenças de tratamento do governo brasileiro na recepção dos imigrantes europeus -, constatam-se indícios de discriminação polônica já no início da sua história no Brasil. Mais que isso, as promessas que haviam sido feitas não foram realizadas. Para Polanczyk (2010, p. 226), “a fixação dos poloneses em seus lotes foi uma verdadeira tragédia. [...] Faltavam hospedarias para receber os imigrantes e não havia lotes demarcados para instalá-los." A hospedaria Ilha das Flores, no Rio de Janeiro, passou a ser chamada de "cemitério de imigrantes" por conta do grande número de pessoas, principalmente crianças, que lá faleceram esperando seu pedaço de terra.

\footnotetext{
7 Tomacheski (2014), na dissertação de Mestrado intitulada A terra prometida da Virgem Maria: imigrantes, viajantes intelectuais e colonos na imigração polaca, considerando a forte religiosidade católica dos poloneses, trata da metáfora bíblica da terra prometida para se referir às terras que os emigrantes da Polônia receberiam ao chegar no Brasil.
} 
De acordo com Polanczyk (2010), os imigrantes poloneses demoraram a receber seu quinhão de terra e, quando isso ocorreu, foi decepcionante. Foram-lhes encaminhadas terras montanhosas, cheias de pedregulhos e de mata fechada. Os primeiros que aqui chegaram foram enviados para terras localizadas entre os italianos, que, ao se instalarem anos antes, já haviam escolhido as melhores propriedades. Além disso, a promessa de moradia na terra que lhes seria destinada não foi cumprida, assim como a de fornecimento de alimentos no primeiro ano. As injustiças cometidas, portanto, em relação a essa etnia no Brasil foram: a sua instalação entre italianos e alemães - considerando sua história de discriminação por parte dos germânicos -, a (falta de) qualidade das terras e a própria discriminação que sentiram ao serem mal recebidos.

O resultado disso foi a revolta de tais imigrantes, ocasionando situações de enfrentamento contra os agentes imigratórios e pequenas rebeliões sucessivas. "Indisciplinados, foram motivo de relatórios amargos redigidos pelas autoridades brasileiras de imigração. Os documentos escritos [...] são homogêneos, isto é, todos expressam uma ideia negativa dos imigrantes poloneses." (POLANCZYK, 2010, p. 233). Há registros históricos, relatos de agentes e funcionários do governo, que descrevem o imigrante colono polaco como inútil, nocivo, vagabundo, com verdadeira aversão ao trabalho, ébrio (GRITTI, 2004), entre outras características nada agradáveis, na maioria das vezes em comparação às outras etnias europeias que já estavam bem instaladas e trabalhando em suas terras. É interessante observar (e ressaltar) que, nesses relatos, é com frequência utilizado o vocábulo "polaco" associado a adjetivos negativos. Isso pode explicar por que muitos polono-brasileiros não gostam de ser assim chamados, e é de extrema importância tratar dessa questão.

A respeito do termo polaco, o jornalista Iarochinski (2003) relata que, certa vez, o presidente de uma associação étnico-cultural no interior do Paraná interrompeu sua entrevista quando ouviu a palavra "polaco", pois ele disse se sentir terrivelmente agredido com algo que equivalia a um palavrão. $\mathrm{O}$ autor perguntou sobre as razões disso, e o polono-brasileiro the respondeu que era pejorativo porque significava burrice e que eram filhos de uma prostituta. O jornalista chegou, em outra ocasião, a ser agredido fisicamente por um polono-brasileiro pelo mesmo motivo.

Intrigado com a situação, o autor - descendente de polonês e orgulhoso de sua origem - resolveu investigar a razão de tamanho desprezo em relação ao vocábulo polaco e descobriu, mediante uma pesquisa histórica que a origem do uso de "polaco" como termo depreciativo iniciou no começo do século XX, no Rio de Janeiro, quando o proprietário do Cassino da Urca havia trazido prostitutas da Europa para trabalhar em seu 
estabelecimento. "Como estas mulheres eram em sua maioria loiras como as 'polacas' do Sul do Brasil, a população começou a qualificá-las de 'Polacas”' (IAROCHINSKI, 2003, p. 14). Depois de um tempo, a população carioca generalizou o uso do vocábulo para fazer referência a prostitutas, independentemente de sua etnia.

Essa questão da figura feminina erotizada de modo negativo consiste em algo que se deve destacar, pois se percebe muito mais o desprestígio quando o termo está no feminino. Wolny (2012) argumenta que a polaca seria vista e tratada de modo muito similar à mulata brasileira, ou seja, "a polaca, tal como a mulata, é um objeto construído através do discurso que lhe atribui as características que denunciam as regras por ele impostas. Trata-se de um discurso masculino, sexualizado, profundamente marcado pelo patriarcalismo e machismo“. (WOLNY, 2012, p. 338). Mas essa questão será retomada na próxima seção, quando analisaremos a entrevista de uma polono-brasileira.

Voltando-se ao contexto histórico, não obstante as dificuldades, ainda tinham esperança no Brasil, e alguns mandavam cartas aos companheiros da Polônia incentivando-os a emigrarem. Houve, então, várias correntes de imigrantes poloneses no Brasil - consoante Gardolinski (1956) - sendo o ano de 1890 o ponto culminante da emigração polonesa, o qual ficou conhecido "na Polônia sob o nome de 'febre brasileira' (goraczka brazylyjska)" (GARDOLINSKI, 1956, p. 16). Ainda segundo o autor, boa parte dos imigrantes queria se direcionar ao Paraná, mas era impossível atender a todos os pedidos. Assim sendo, a maior parte foi levada ao Rio Grande do Sul, e a segunda maior contingência foi no Paraná. Também há presença de pequenos núcleos nos estados do Rio de Janeiro ${ }^{8}$, Espírito Santo, São Paulo, Minas Gerais e Mato Grosso. É curioso observar que as aldeias polonesas tinham até mesmo uma lenda religiosa católica envolvendo o estado do Paraná, de acordo com o que mostra Wachowicz (1981, p. 45): “o Paraná até então estava coberto por névoas e que ninguém sabia de sua existência. Era a terra em que corria leite e mel. Então a Virgem Maria, madrinha e protetora da Polônia, ouvindo os apelos que o sofrido camponês polonês lhe dirigia, dispersou o nevoeiro e predestinou-lhe o Paraná."

A imigração no estado do Paraná, então, no século XIX começou a receber uma grande contingência de correntes de imigrantes: alemães, poloneses, italianos, ucranianos, sírio-libaneses, austríacos, franceses, ingleses, holandeses. As diferenças culturais entre essas etnias repercutiram na construção do Brasil, e, nesse sentido, de acordo com Wachowicz (2010), os poloneses tiveram maior influência no quadro rural, enquanto os alemães se destacaram no meio urbano. "Algumas indústrias e os sobrados curitibanos de fim do século XIX são marcadamente produto da influência alemã, enquanto no

\footnotetext{
${ }^{8}$ Para mais detalhes sobre a presença de poloneses no Rio de Janeiro, conferir Malczewski (1998).
} 
meio rural e nas estradas paranaenses vão se destacar a carroça polaca e o carroção eslavo". (WACHOWICZ, 2010, p. 328).

A respeito dessa multiplicidade étnica, Nadalin (2001, p. 79) afirma que "a composição étnica majoritária dos colonos neste novo período concentrou-se em italianos e poloneses em 1880-89, e em poloneses, italianos e alemães em 1890-99, com um novo colorido proporcionado pela participação significativa de ucranianos." Ainda conforme o historiador, entre 1829 e 1911, 83.012 colonos estrangeiros se instalaram no Paraná. Havia, porém, um baixo índice de fixação desses imigrantes nas suas colônias originais (como no Rio Grande do Sul, por exemplo), pelo fato de não haver condições de desenvolvimento suficientes. Por essas e outras razões, houve fluxo remigratório para o Paraná, principalmente para a capital. Com isso, Nadalin (2001) afirma que mais de $100 \mathrm{mil} \mathrm{imi-}$ grantes instalaram-se na região até 1934. (NADALIN, 2001, p. 79).

Essa questão do fluxo remigratório é mencionada também por Polanczyk (2010), ao explicar que os colonos poloneses instalados no Rio Grande do Sul, com o crescimento familiar, precisaram de mais terras para distribuir a seus filhos. Com isso, "reiniciava-se o ciclo, os filhos dos emigrantes passaram a buscar novas colônias no Alto Uruguai, as gerações dos seus netos povoaram o oeste de Santa Catarina e do Paraná, e as de seus bisnetos estão em todos os polos agrícolas do Brasil” (POLANCZYK, 2010, p. 268).

Nadalin (2001, p. 80) trata dessa questão, explicando que "tendo como ponto de partida os primeiros núcleos coloniais plantados no Rio Grande do Sul desde a década de 1820, descendentes de imigrantes ocuparam as regiões florestais desdenhadas pela sociedade tradicional”. Eles ultrapassaram o estado do Rio Grande do Sul, colonizando o oeste de Santa Catarina e também, a partir de 1920, o Sudoeste e o Oeste do Paraná.

Nesse sentido, é preciso esclarecer que os poloneses que imigraram no século XIX para o Paraná o fizeram mais especificamente na mesorregião metropolitana de Curitiba e também na mesorregião sudeste do Paraná (onde se situam Irati, Cruz Machado, Mallet, entre outros municípios), instituindo as colônias mais antigas de poloneses no chamado "Paraná Velho" - como nomeiam os historiadores. "A primeira colônia fundada por iniciativa do município de Curitiba e que foi destinada exclusivamente aos imigrantes poloneses foi a Colônia do Abranches, criada em 1873." (ROCHA, 2015, p. 65).

Ainda nas mesorregiões metropolitana de Curitiba e sudeste do Paraná, Foetsch (2005, p. 40) explica como se deu o processo de instalação dos imigrantes polônios: "A colonização do Distrito de Rio Claro do Sul, por sua vez, deu-se a partir de 1884, quando se iniciavam as medições de terras para formações de núcleos coloniais da região sul do Paraná." 
Já as outras mesorregiões (situadas mais a oeste, como sudoeste, centro-sul e oeste) - ainda na parte sul do Paraná, da área histórico-cultural denominada frente sulista (cf. WACHOWICZ, 2010) - tiveram origem em meados da década de 1950 e receberam polono-brasileiros que já estavam instalados em outros estados do Brasil. No mapa a seguir, é possível observar as mesorregiões citadas, focalizando-se a mesorregião centro-sul, onde se situam os informantes desta pesquisa (cidade de Quedas do Iguaçu - PR).

Figura 1. Mesorregiões do Paraná

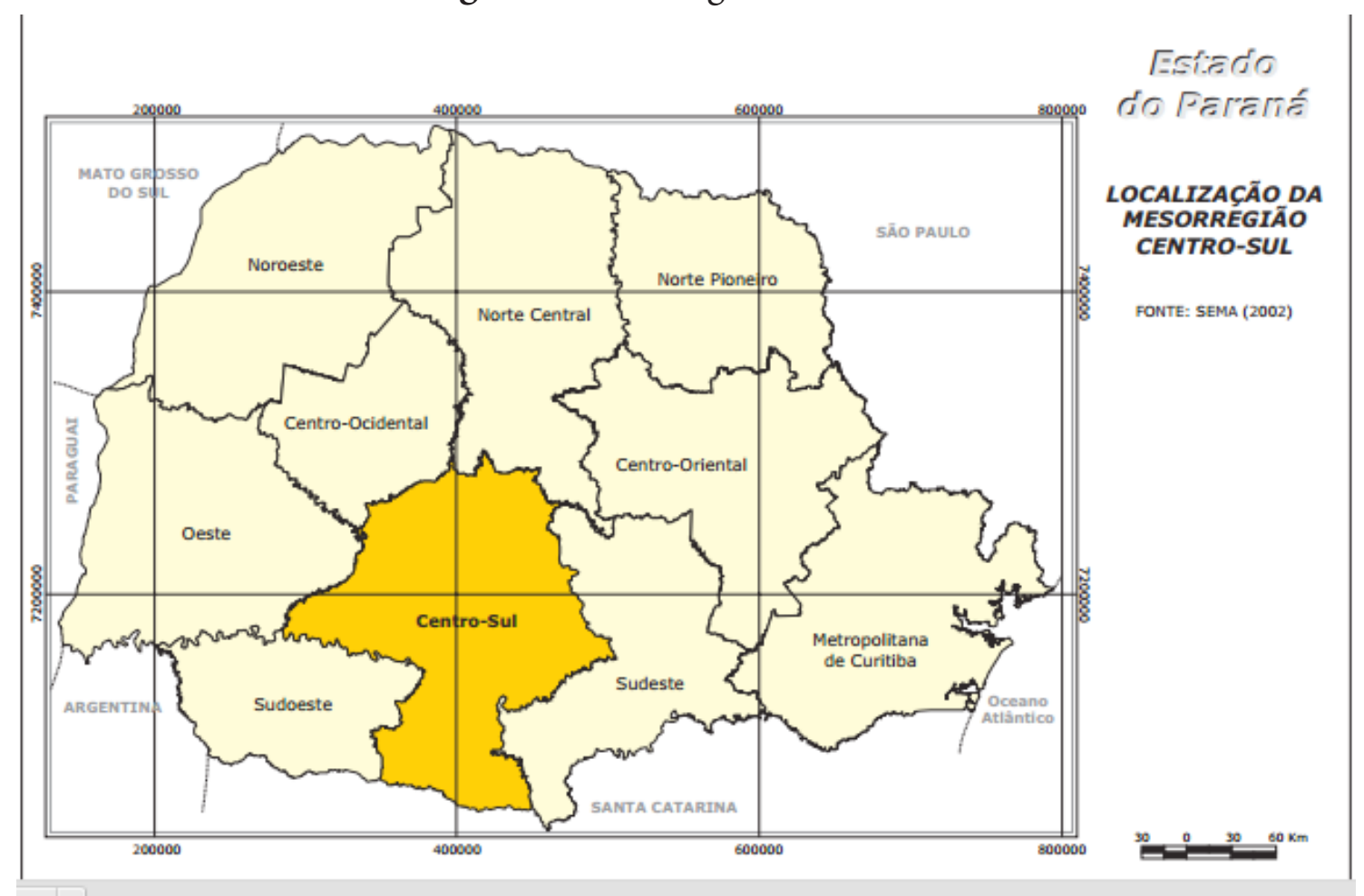

Fonte: IPARDES (2004, p. 06).

Após reinstalados em outras localidades ou permanecendo em "colônias velhas" (POLANCZYK, 2010) - i.e., suas colônias de origem -, os polono-brasileiros, aproximadamente na década de 1920, já estavam mais familiarizados com as terras brasileiras e mantinham sua cultura com significância. Instalaram escolas polonesas (GARDOLINSKI, 1976), faziam pratos poloneses tradicionais (não obstante tivessem já incorporado alimentos tipicamente brasileiros em sua culinária), mantinham as festas religiosas católicas e falavam o polonês em suas esferas sociais.

Rocha (2015, p. 64) explica que "um elemento importante no que se refere aos hábitos da comunidade polonesa no Paraná é a forte religiosidade presente entre seus membros. A prática do rito católico é uma marca relevante dessa população tanto entre 
relatos dos antigos colonos quanto nos dias atuais."

No entanto, na década de 1930, passaram por mais um momento de restrição e silenciamento, o qual, dessa vez isso não se direcionou somente a eles, mas também a outras etnias imigrantes no Brasil. Tratava-se de um projeto de nacionalização, quando "vieram os decretos do Estado Novo em 1937, proibindo o ensino de outras línguas, o uso de símbolos, da língua e nomes estrangeiros." (POLANCZYK, 2010, p. 276).

A respeito disso, Oliveira (2009) faz um apanhado geral do que ocorria na época e das repercussões desse projeto. O Decreto-Lei n. 383 (1938) proibiu os estrangeiros o exercício de qualquer atividade política, de manter jornais, revistas ou outras publicações. Já “o Decreto-Lei no 1.545 (1938) proibiu o uso de línguas estrangeiras em qualquer espaço público. [...] As comunidades polonesas no Paraná [...] foram consideradas perigosas à soberania nacional" (OLIVEIRA, 2009, p. 7).

Essa fase histórica no Brasil trouxe repercussões desastrosas para as etnias imigrantes. No referente aos polono-brasileiros, Polanczyk (2010, p. 278) lamenta que muitos descendentes "não tiveram nenhuma oportunidade de aprender a língua polonesa. [...] Como preservar a cultura [...]? Os pais não puderam transmitir aos filhos a cultura e os costumes dos avós." O autor ainda complementa que muitos descendentes de poloneses desconhecem a língua, sabem muito pouco sua cultura, restando-lhe quase que unicamente o sobrenome polonês, muitas vezes abrasileirados (por diversos motivos, mas se destaca o desconhecimento dos cartorários que registravam esses polono-brasileiros erroneamente).

A partir disso, retomaremos, na próxima seção, as seguintes questões: i) repercussões do processo histórico constante (e repetitivo) de despolonização; ii) o preconceito antipolônico contemporâneo; iii) o uso (atual) do termo polaco como um estereótipo depreciativo para se referir a polono-brasileiros; iv) o sentimento de polonidade (e/ou sua ausência); e v) outras questões relativas aos depoimentos dos polono-brasileiros.

\section{Discussão e análise de entrevistas com polono-brasileiros}

Nesse contexto histórico de silenciamento e discriminação que temos mostrado, acreditamos que os polono-brasileiros passaram por processos ativos e passivos de desvalorização da sua pluralidade linguística e cultural, conforme se pode observar no quadro a seguir: 
Quadro 1: Contínuo das modalidades de políticas linguísticas

\begin{tabular}{|l|ll|}
\hline \multirow{2}{*}{ [+ passivo] } & {$[$ monolg] -} & + [plurilg] \\
\cline { 2 - 3 } & $\begin{array}{l}\text { Silêncio } \\
\text { (indiferença }>\text { omissão }>\text { antipatia })\end{array}$ & $\begin{array}{l}\text { Tolerância } \\
\text { (simpatia }>\text { empatia })\end{array}$ \\
\cline { 2 - 3 } & $\begin{array}{l}\text { Assimilação } \\
\text { Discriminação }>\text { incriminação }\end{array}$ & $\begin{array}{l}\text { Pluralidade } \\
\text { Discurso retórico }>\text { participação }\end{array}$ \\
\cline { 2 - 3 } & $\begin{array}{l}\text { Silenciamento } \\
\text { [+ ativo }\end{array}$ & $\begin{array}{l}\text { Promoção } \\
\text { (reconhecimento }>\text { ações })\end{array}$ \\
\hline
\end{tabular}

Fonte: Altenhoffen (2013, p. 103).

Nosso objetivo é mudar essa direção, e, por isso, a exposição e análise das entrevistas com polono-brasileiros pretendem "dar voz" e, sobretudo, "dar ouvidos" às suas necessidades na contemporaneidade, considerando o que aponta Altenhoffen (2013, p. 96). Além disso, almejamos a propagação e valorização do plurilinguismo brasileiro, inclusive da língua polonesa, por meio da desconstrução do "mito do monolinguismo" (cf. MAHER, 2013, p. 118). Esses descendentes de poloneses que ainda interagem em suas línguas maternas representam "ecos de resistência" diante do cerco realizado às línguas de imigrantes no Brasil (MAHER, 2013).

As entrevistas analisadas neste artigo são pertencentes ao banco VARLINFE (Variação Linguística de Fala Eslava, ligado ao NEES - Núcleo de Estudos Eslavos UNICENTRO, campus de Irati), composto por 24 entrevistas gravadas (com duração aproximada de uma hora), de oito cidades paranaenses (Irati, Ivaí, Mallet, Rebouças, Rio Azul e Prudentópolis) - o qual está atualmente em processo de ampliação, mediante a coleta em outras duas cidades paranaenses - Quedas do Iguaçu, no centro-sul, e Cruz Machado, no sudeste.

Assim como as demais, as entrevistas selecionadas ${ }^{9}$ seguiram a metodologia da Sociolinguística Quantitativa laboviana (LABOV, 2008; TARALLO, 1990), havendo um roteiro de perguntas ${ }^{10}$ que procuravam despertar a fala menos monitorada dos sujeitos (vernáculo $)^{11}$, mediante temas como: origem familiar, histórias e memórias de infância, situações de tragédia familiar, festividades religiosas, culinária típica, manifestações culturais, uso da língua materna (polonesa), iniciação escolar, relações interétnicas, situações de preconceito, entre outras que possam surgir ocasionalmente.

\footnotetext{
9 Todas as entrevistas do banco foram feitas por professores ou alunos da universidade, devidamente capacitados para tanto, e as de Quedas do Iguaçu estão sendo feitas pela autora deste artigo.

${ }^{10}$ Verificar Costa e Loregian-Penkal (2015) para mais detalhes sobre o passo a passo da coleta do banco inicial; o roteiro de perguntas; as características geográficas da região, entre outros pontos.

${ }^{11}$ Como se pode observar, as entrevistas sociolinguísticas em questão foram feitas para fins de uma linha teórica específica, mas isso não nos impede de utilizá-las para pesquisas da área de História e Políticas Linguísticas, por exemplo.
} 
A análise, por sua vez, neste momento tem caráter qualitativo, transcrevendo-se trechos de dois informantes com mais de 50 anos (e menos de 70), irmãos, mulher e homem, cuja língua materna é a polonesa, residentes e nascidos em Quedas do Iguaçu, ambos envolvidos com atividades de manutenção da cultura polonesa e o Grupo Folclórico Jagoda (grupo polonês da cidade). Eles relataram que seus avós vieram da Polônia, em um navio alemão, antes da guerra, e que algumas pessoas desembarcaram no Espírito Santo, Rio de Janeiro, Paranaguá e depois em Porto Alegre, sendo que a maior parte foi para o Rio Grande do Sul.

Outra característica importante é que os dois sujeitos aprenderam o português (na sua modalidade oral e escrita) apenas quando foram para a escola, pois em casa e entre os vizinhos só falavam polonês. Isso demonstra que seus pais, apesar do projeto de nacionalização na década de 1930, mantiveram a língua em situações familiares.

Mais que isso, um dos entrevistados relatou que fazia aulas particulares com um professor vindo diretamente da Polônia, após a Segunda Guerra Mundial, dominando também a escrita da língua. Sua irmã, também entrevistada, aprendeu com ele a escrever. Consiste num dado interessante o fato de ambos conhecerem a escrita de sua língua materna, pois uma parte considerável dos polono-brasileiros não teve essa oportunidade e até mesmo não se interessou em aprender, como relatam os próprios informantes desta pesquisa.

O primeiro entrevistado atuou muitos anos como radialista de um programa polono-brasileiro, no qual apresentava canções polonesas (principalmente religiosas), histórias da sua etnia, notícias da Polônia, entre outras manifestações culturais que permitiram fortalecer a polonidade dos seus descendentes. A segunda entrevistada é enfermeira e trabalha com dança polonesa no grupo polônico, ensinando aos mais jovens as tradições culturais de sua etnia. Percebe-se, pois, que os dois sujeitos apresentam um sentimento de pertencimento polonês muito forte.

Dando ouvidos à primeira entrevista, observemos o trecho transcrito ${ }^{12}$ de diálogo entre a entrevistadora e o polono-brasileiro, quando fala sobre o antigo nome da cidade:

Entrevistadora: O nome da cidade foi Jagoda?

Entrevistado: Sim. Foi Jagoda, posteriormente Campo Novo e último Quedas do Iguaçu. Eu não sei por que que eles fizeram assim. Foi o Fulano [nome omitido, prefeito da época] que fez assim.

\footnotetext{
${ }^{12}$ As entrevistas foram transcritas o mais próximo possível da norma padrão da língua portuguesa, sem considerar variações linguísticas, como apagamento do / R/ final, uso do tepe, monotongação, abaixamento voc entre outras questões que nos interessam muito na Sociolinguística Quantitativa Laboviana.
} 
Entrevistadora: E o prefeito era descendente de polonês?

Entrevistado: Não, ele era alemão.

Entrevistadora: Ah...

Entrevistado: E lá na Argentina, a irmã dessa Jagoda, que Jagoda em polonês representa "frutas", mas o nome da filha do Piosusky, presidente da Polônia, é Jagoda. Por isso, deram o nome de Jagoda. A outra era a Edwiges, e daí eles teriam um terreno na Argentina e deram o nome de Edwiges. E o município saiu com o nome Edwiges. E aqui não...

Entrevistadora: Que coisa...

Entrevistado: Né? Ninguém dos poloneses assim, não, não se tocaram que ele pode trocar, né? Foi lá e trocou e depois acabou-se [tosse].

Entrevistadora: E na época, os poloneses não se uniram assim pra reivindicar?

Entrevistado: Pois o que eu digo que, não é que... As crianças hoje são mais adiantadas que... As criancinhas praticamente recém-nascidas do que antigamente os pais...

Entrevistadora: Hum... Não sabia que podia ir atrás?

Entrevistado: É... não, não corriam atrás disso. Não tinha, era... Uma por causa da dificuldade, porque, veja bem, no- no começo era tudo feito a cavalo e carroça, então, depois, quando passou a município, já tinha- tinha... meios de transportes, automóveis e caminhões, e tudo. Isso é normal. Já, depois foi sair o município. Mas no princípio ali era só... então por isso o pessoa vivia assim, bem, bem. Uma amizade, uma fraternidade mútua, né? Mas eles não tinham assim um desenvolvimento, é... que fosse... político. Né? Isso não, isso, pra eles era trabalhar, igreja... faziam seus matinês, né? E pra, assim, pra se alegrar, pescaria, caça, e era o divertimento deles. Agora, politicamente, eles não se metiam em nada. Que nem hoje, né, acontece... Pra eles isso aqui não era...

Entrevistadora: Importante?

Entrevistado: Negativo.

Esse trecho da entrevista é bastante congruente com a história que apresentamos, pois mostra o sentimento de inferioridade dos polono-brasileiros, que foi instituído pelas constantes iniciativas de silenciamento ocorridas na Polônia e no Brasil. O camponês polonês não parecia querer se envolver com política, preferindo ficar calado diante da liderança principal da cidade. Isso está de acordo com o que afirmam estudiosos (GARDOLINSKI, 1956; MALCZEWSKI, 1998; WACHOWICZ, 2010) ao mencionarem que imigrante polonês trazia consigo uma postura, ainda, de subserviência. $\mathrm{O}$ resultado de terem se calado, na época, foi a mudança do nome do município pelo prefeito de origem alemã.

O entrevistado também relatou que, na escola, era terminantemente proibido falar polonês, e eles assim obedeciam. Segundo ele afirma, depois de um tempo que o exército 
assumiu o governo brasileiro, vieram alguns soldados à cidade para prender o professor que lhe dava aulas de polonês, pois achavam que ele era "comunista". Inquiriram-no e verificaram que as aulas eram particulares, então não podia prendê-lo, pois era proibido no ensino oficial apenas. Vê-se, então, mais uma prática que rumava ao processo histórico de despolonização.

Ainda sobre essa questão da interdição linguística, a segunda entrevistada, ao tratar das origens imigratórias de sua família, afirma:

Entrevistada: Eles vieram para cá, porque aqui tinha uma companhia polonesa. E era época da Segunda Guerra Mundial, e era proibido falar polonês. [...] Quem falasse polonês, seria massacrado. [...] Mas muitos poloneses são daquela época, das terras daquela época. Meu pai acabou vendendo porque era atrás do Campo Novo, né? Trocou com a Araupel mais para cá, né? [...] E por isso que os poloneses vieram para cá, né? Para comprar essas terras. [...] Então, tem uma história muito bonita desses poloneses.

É possível, a partir desse trecho, além de verificar a questão do interdito, estabelecer uma relação com o contexto histórico de fluxo remigratório de muitos polono-brasileiros para o Paraná após a década de 1920. A família entrevistada foi um desses casos, incentivada pela existência de uma companhia polonesa. Nesse sentido, vale ressaltar a relação dessa companhia com a Igreja Católica, que também auxiliou esses sujeitos em sua manutenção cultural, tratando-se de um “unificador cultural” (GARDOLINSKI, 1956). Hodiernamente, são feitas missas em polonês uma vez por mês, além de os padres da cidade virem da Polônia diretamente ao Brasil.

Mudando-se o tópico, ao ser questionado se já havia sofrido preconceito por ser polonês, o entrevistado disse que isso raramente ocorria, mas que algumas vezes se utilizou da língua materna para conversar em segredo com seus companheiros étnicos na frente dos colegas de trabalho. É importante salientar, no entanto, que outro entrevistado da mesma família (irmão mais novo) relatou sofrer preconceito e ser chamado de "polaco" em tom pejorativo. Ainda sobre essa questão, a irmã do entrevistado trata sobre a ausência do sentimento de polonidade entre muitos que a rodeiam, relatando algumas ocasiões em que foi vítima de preconceito por ser "polaca”.

Entrevistada: Muitos têm vergonha de ser polonês, têm vergonha de sua própria língua, têm vergonha de falar em polonês.

Entrevistadora: É isso que eu ia perguntar também, se você já sofreu algum preconceito por ser polonesa. 
Entrevistada: Já.

Entrevistadora: Aqui na cidade?

Entrevistada: Já (com ênfase).

Entrevistadora: E o que que aconteceu, assim?

Entrevistada: É, bastante assim, porque, assim, eu sempre digo: o polaco é o avesso do negro.

\section{Entrevistadora: Sério?}

Entrevistada: É. Se hoje tu chamar alguém de negro, porque, se hoje tu chama alguém de negro, porque, às vezes, tu chama brincando: "ô, neguinha, né, ô, negão, né?" Brincando é uma coisa. Agora se tu, de repente, discutir e chamar alguém de negro, te processa. Agora, alguém cham- chegar e dizer assim "polaco lambido", "polaco isso", "polaco aquilo", esses "polaco", então... (ininteligível) esse ano em 2013, quase processei um médico... Entrevistadora: Sério?

Entrevistada: Sim. Porque ele chegou assim na minha mesa e bateu, porque a nutricionista é descendente de polonês também, a quarta geração, é descendente de polonês. E ela é bem branquinha assim e não sei o que que aconteceu que ele chegou pra mim, bateu e disse: "Você vai dá um jeito, esses polacos." Ele falou pra mim assim, que, tipo assim, que nós éramos, né. Daí eu disse: "Escuta aqui, não pense que, não pense que eu já não me informei. Racismo é qualquer tipo de raça, não é só negro." Falei "não é só negro." Falei "qualquer tipo de raça." E daí falei: "Doutor Fulano [omitido], um dia que alguém me ofender com um negócio assim de- de- de-, porque, ah, polaca, tudo bem, né, agora vim de fal-, chamar do jeito que me chamaram... "Sei que eu não gosto de polaco, porque esses polaco, porque não sei o quê..."

Entrevistadora: E essa pessoa que foi preconceituosa, ele tinha que descendência, assim?

Entrevistada: (Inintelígivel) gringo, italiano.

Entrevistadora: Hum...italiano. Tem uma richa entre os italianos, alemão e polonês, né?

Entrevistadora: Sim...

Entrevistada: É... mas...a- o- u-, eu acho que ainda o alemão e o polonês se dão mais...

Entrevistadora: Se dão melhor...

Entrevistada: Porque os trajes são mais parecidos. As danças são mais parecidas, entende? Os- a- o- a culinária é mais parecida. Tudo é mais parecido, né? Então, os gringos, acho que com os poloneses são meio "provalecido". Então, eu já, eu tinha uma colega minha, que um dia eu mandei ela calar a boca, também falei, porque ela qualquer coisa, chamava, porque, não a mim, mas qualquer outra pessoa que é descendente, ah, "polaca lambida”, né, pra mim aquilo lá era uma ofensa!

Entrevistadora: Sim...

Entrevistada: Daí um dia eu falei: "Escute aqui." E ela é descendente de italiana. Aí falei "Escute aqui", agora ela já até faleceu, "Escute aqui, por que que você fica falando? Eu me ofendo! Eu me ofendo com isso!!" "Ah, mas não estou falando pra você" - "É, tá falando da minha origem, da minha raça, eu me ofendo, porque não é lambido. Se eu tenho o cabelo escorrido, é a natureza. Se os polacos têm o cabelo escorrido, é porque é assim. É pra ser assim." E daí, e daí foi e sei que eu fu- chegou até um ponto d'eu, eu vou processar, porque, porque não é só nego. Eu, eu num fico chamando ali, como diz, eu gosto da raça negra. Admiro. Né? Porque eu 
acho bonito um moreno, não sei se é porque a gente é branco, mas eu acho muito bonito, que nem essa minha amiga professora que me ajudou a dar os ensaio de dança ali, que casou com um preto, as criança coisa mais linda dela, porque ela misturou as raça. Ela é loira, e ele, bem morenão, negão forte, assim, e o pequininho faceirinho, igual ele, sabe? Então, assim, eu admiro, mas eu não fico ofendendo as pessoas, né? Então o polonês, ele é muito discriminado...

No referente a esse trecho, observa-se que a descendente polônica não apresenta preconceito no que diz respeito à miscigenação e é bastante consciente dos seus direitos, manifestando-se contra situações de preconceito. Ademais, é possível notar a questão da discriminação de outras etnias europeias em relação aos "polacos", conforme já havia apontado Borstel (2005) ao observar situações de relação interétnica (entre alemães e poloneses) no oeste do Paraná. O fato também de ela mencionar que "o polaco é o avesso do negro" revela que, como aponta Wolny (2012), é possível estabelecer uma ligação entre o preconceito e a construção social sexualizada da mulata (e, talvez, mesmo do mulato) com a figura do polaco e da polaca.

Outro ponto a se mencionar é o fato de a polono-brasileira tentar se comunicar com poloneses por meio das redes sociais, manifestando, mais uma vez, sua forte polonidade.

Entrevistada: E daí como veio esse Face, a gente foi vendo, tinha muito [sobrenome da família omitido], e um compartilhava com o outro, sabe, curtia, e daí a gente, no fim, aqui eles estavam mais interessado, começavam a fazer perguntas, (ininteligível) se a gente sabia falar polonês, daí viram, quando viam que a gente falava polonês, aí a gente começava a se corresponder, comunicar com eles ali. Aí tem uma mulher que me mandou já duas vezes presente de lá.

Depois desse relato, ela mostrou uma carta escrita a um polonês que, num texto de jornal, convocou os polono-brasileiros que quisessem saber sobre a história da sua família a lhe escrever. Tempos depois, a carta lhe foi respondida, e o sujeito veio visitá-la na cidade. Relacionado a isso, tanto a entrevistada quanto o irmão demonstraram ter vontade de ir para a Polônia, mas ainda não o fizeram.

Quanto à língua polonesa, nenhum de seus filhos é falante. Eles reconhecem que não insistiram em ensinar, mas também que seus filhos e as novas gerações não se interessam em aprender. Afirmam que, quando crianças, participam do grupo e de manifestações culturais, porém, no momento em que iniciam o ensino superior, afastam-se e sofrem um apagamento de sua polonidade. Slodkowski (2013) também percebeu essa questão da identidade polonesa enfraquecida entre os mais jovens, e isso demonstra, mais uma vez, a 
extrema necessidade de se traçarem políticas linguísticas de promoção dessa cultura, em detrimento a todo silenciamento histórico vivenciado.

\title{
Considerações finais
}

Com base no contexto histórico apresentado e na análise das duas entrevistas com polono-brasileiros, identificamos as marcas de silenciamento deixados na história desses sujeitos, além de situações de preconceito que ocorrem contemporaneamente, embora estejam mais relacionadas à figura da polaca e, menos, à do polaco. Argumentamos que existam raízes históricas para tanto (GARDOLINSKI, 1976, DOUSTDAR, 1990; IAROCHINSKI, 2001, 2003; GRITTI, 2004; BORSTEL, 2005; POLANCZYK, 2010; WOLNY, 2012) e procuramos entender como se deu esse processo (repetido) de desvalorização da cultura e língua polonesa no Brasil.

Conhecendo-se a história, conseguimos não apenas compreender a realidade atual, mas intervir diante dos acontecimentos, pois, conforme Doustdar (1990, p. 7-8):

\begin{abstract}
A história não é apenas o levantamento de dados ou fatos, mas o entendimento das relações entre os fatos e interpretação de seu sentido. A história, como toda a forma de conhecimento, procura explicar uma relação desconhecida, dando origem a duas ordenes de elementos: os fatos e sua interpretação, inseparavelmente ligados num trabalho de história. [...] Quando se analisa o passado, fazemos indagações com as perguntas que nos interessam hoje, avaliando a significação desse passado na sua relação conosco. Quando usamos as perguntas de hoje adquirimos o passado pela sua permanência no mundo atual, pois somos o passado plenamente desenvolvido.
\end{abstract}

Nesse sentido, levamos também em consideração o papel das Políticas Linguísticas, aliadas às áreas da História e Geografia, para pensar em atividades de intervenção nessas realidades. Conforme Oliveira (2016, p. 386), construir políticas linguísticas:

é participar da construção do futuro das sociedades, e mais especificamente da nossa sociedade; fazer política linguística, pela própria noção de intervenção sobre as línguas, sem a qual ela não existe, é atuar para um mundo mais justo neste campo específico das línguas e dos seus usos, mais plural, mais democrático e mais aberto à ecologia de saberes humanos." É reconhecer que também no campo do uso das línguas há constantemente assimetrias de poder que favorecem a uns e calam os outros, assimetrias que constantemente combateremos com os instrumentos da planificação ou planejamento linguístico, numa guerra que finalmente não temos (historicamente) como ganhar definitivamente, mas na qual podemos vencer muitas batalhas importantes, "combatendo o bom combate". 
Não se trata de alimentar um sentimento de orgulho alienante que menospreze outras culturas. Pelo contrário, a ideia é de valorização do multilinguismo brasileiro, incluindo-se o polonês. Por conta disso - em oposição a todo silenciamento sofrido -, aos polono-brasileiros do sul do Paraná, procuramos dar voz às suas memórias e ouvidos às suas necessidades, de modo a pensar estratégias de propagação e promoção cultural da etnia polonesa.

Como uma das mudanças necessárias para a promoção linguística, com vistas a fortalecer a consciência do plurilinguismo, consideramos a importância de se estabelecer a cooficialização da língua polonesa na cidade de Quedas do Iguaçu e também nas cidades do sul do Paraná (e do restante do Brasil) marcadas pela influência étnica polônica. Conforme Oliveira (2016, p. 391):

\begin{abstract}
A cooficialização de línguas em nível municipal, através de lei promulgada pela câmara de vereadores, é um verdadeiro movimento social no Brasil, que conta já com 11 línguas oficializadas em 19 municípios, 7 línguas indígenas e 4 línguas alóctones ou de imigração, em sete estados brasileiros nas regiões norte, centro oeste, sudeste e sul.
\end{abstract}

Além disso, com base no depoimento de um dos entrevistados, percebe-se a necessidade do oferecimento de formação específica para cartorários de regiões plurilíngues, haja vista que muitos descendentes tiveram seus sobrenomes adulterados por conta da incipiência desses profissionais. Isso ocasionou (e ocasiona) muitos problemas para os polono-brasileiros em decorrência de haver divergências entre seus documentos e dos seus pais, ou, até mesmo entre seus próprios documentos (RG com uma grafia, CPF com outra, por exemplo).

Outra estratégia de valorização e manutenção da cultura polonesa seria a busca de mais espaços (além da igreja católica e do espaço físico do Grupo Folclórico Jagoda) para a divulgação de sua língua e cultura. Seria possível, também, organizar cursos instrumentais de língua polonesa, os quais poderiam ser oferecidos pelos polono-brasileiros que dominam a escrita da língua, com o auxílio metodológico de docentes pedagogicamente preparados.

Em relação a ações para a continuidade da cultura polonesa, Slodkowski (2013, p. 93) traz como exemplo o que ocorre em Guarani das Missões (RS), onde "a Prefeitura Municipal, através da lei municipal, isenta de impostos os habitantes que construírem ou reformarem suas casas em estilo polonês." Se, por um lado, isso diminui a arrecadação de impostos, por outro incentiva o turismo local, por conta da belíssima arquitetura polo- 
nesa. Outra questão mencionada por um dos entrevistados é a questão da mudança do nome do município, e o retorno ao nome original (Jagoda) seria uma distinta forma de valorização da cultura local.

Assim como outros polono-brasileiros, os entrevistados manifestam seu desejo de conhecer a sua pátria de origem, num anseio de descobrir histórias de suas famílias e de conhecer mais de perto suas raízes. Poderiam, desse modo, ser organizadas viagens periódicas com grupos de pessoas interessados em fazer uma viagem cultural para a Polônia.

Essas propostas seriam colocadas em prática de modo mais substancial se houvesse a implantação da BRASPOL na cidade, já que sua ausência parece dificultar o fortalecimento da polonidade da população. Por fim, com base na voz da polono-brasileira que entrevistamos, acreditamos ser essencial a participação da mulher polaca na sociedade paranaense, possibilitando a elas cargos de liderança e a valorização do papel feminino, a fim de que os "perfis polônicos brasileiros" (WACHOWICZ; MALCZEWSKI, 2000) não continuem sendo masculinos, em sua maioria.

\section{Referências}

ALMEIDA, J. F.; ZANINI, M. C. C. Para além de uma antropologia das perdas: identidades polonesas e memórias. Antares: Letras e Humanidades, vol.5, n¹0, jul-dez, 2013.

ALTENHOFEN, C. V. Bases para uma política linguística de línguas minoritárias no Brasil. In: NICOLAIDES, C.; SILVA, C. A.; TILIO, R.; ROCHA, C. H. Política e Políticas Linguísticas. Campinas, SP: Pontes Editores, 2013.

BORSTEL, C. N. V. O conflito étnico/cultural e interlinguístico de descendentes de poloneses. Espéculo. Revista de estudios literários, Universidad Complutense de Madrid, n. 31, 2005. Disponível em: https://pendientedemigracion.ucm.es/info/especulo/numero31/polones.html. Acesso em: 20 jan. 2017.

CALVET, L.-J. As políticas linguísticas. São Paulo: Parábola Editorial; IPOL, 2007.

COSTA, L. T.; LOREGIAN-PENKAL, L. A coleta de dados do banco VARLINFE - variação linguística de fala eslava: peculiaridades e características. Revista Conexão, v. 11, n.1, jan./abr., 2015.

DELONG, S. R.; KERSCH, D. F. Perfil de descendentes de poloneses residentes no sul do Brasil: a constituição da(s) identidade(s). Revista Domínios de Linguagem, v. 8, n. 3 ago./dez., 2014.

DOUSTDAR, N. M. Imigração Polonesa: raízes históricas de um preconceito. Dissertação de Mestrado. Curitiba: UFPR, 1990.

FOETSCH, A. A. Paisagem, cultura e identidade: os poloneses em Rio Claro do Sul Mallet - PR. Dissertação (Mestrado) - Universidade Federal do Paraná, Setor de Ciências 
da Terra, Curso de Pós-Graduação em Geografia Orientadora: Profa. Dra. Cicilian Luiza Lowen Sahr, Curitiba, 2007.

GARDOLINSKI, E. Escolas da colonização polonesa no Rio Grande do Sul. Porto Alegre: Escola superior de Teologia São Lourenço de Brindes; Caxias do Sul, Universidade de Caxias do Sul, 1976.

GARDOLINSKI, E. Imigração e colonização polonesa, 1956. Disponível em: https://www. ufrgs.br/biblioestudosetnicos/wp-content/uploads/2014/04/Gardolinski-Edmundo.Imigra\%C3\%A7\%C3\%A3o-e-Coloniza\%C3\%A7\%C3\%A3o-Polonesa.pdf Acesso em: 20 jan. 2017.

GRITTI, I. R. Imigração e colonização polonesa no Rio Grande do Sul. A emergência do preconceito. Porto Alegre: Martins Livreiro, 2004.

IAROCHINSKI, U. Saga dos Polacos: A história da Polônia e seus emigrantes no Brasil. Edição do autor. Curitiba. 2001.

IAROCHINSKI, U. Porque Polaco. Orientação de Prof. Dr. Hab. Piotr Franaszek. Universidade Jaguielônica Instituto de História, Cracóvia, Polônia, 2003.

IPARDES. Leituras regionais: mesorregião geográfica do centro-sul paranaense. Curitiba: IPARDES; BRDE, 2004.

LABOV, W. Padrões Sociolinguísticos. São Paulo: Parábola, 2008.

MAHER, T. M. Ecos de Resistência: Políticas Linguísticas e Línguas Minoritárias no Brasil. In: NICOLAIDES, Christine; SILVA, Cléber Aparecido da; TILIO, Rogério; ROCHA, Claudia Hilsdorf. Política e Políticas Linguísticas. Campinas: Pontes Editores, 2013.

MALCZEWSKI, Z. A presença dos poloneses e da comunidade polônica do Rio de Janeiro. Varsóvia: Oficina Gráfica da Universidade de Varsóvia, 1997.

NADALIN, S. O. Paraná: ocupação do território, população e migrações. Curitiba: SEED, 2001.

OLIVEIRA, M. Os poloneses do Paraná (Brasil) e a questão da nacionalização dos imigrantes (1920-1945). ANPUH - XXV SIMPÓSIO NACIONAL DE HISTÓRIA - Fortaleza, 2009. Disponível em: http://anais.anpuh.org/wp-content/uploads/mp/pdf/ANPUH. S25.0879.pdf Acesso em: 20 jan. 2017.

OLIVEIRA, G. M. Políticas Linguísticas: uma entrevista com Gilvan Müller de Oliveira. ReVEL, v. 14, n. 26, 2016.

POLANCZYK, A. J. O imigrante polonês e a colônia Guarany. Porto Alegre: Renascença; Edigal, 2010.

ROCHA, R. M. Histórico da imigração polonesa na região metropolitana de Curitiba. CSOnline - Revista Eletrônica de Ciências Sociais, Juiz de Fora, Ano 8, E. 19, jan./jun., 2015, p. 52-76. 
RODYCZ, W. C. (Org). Colônia Lucena, Itaiópolis: Crônica dos imigrantes poloneses. Florianópolis: BRASPOL, 2002.

SLODKOWSKI, A. C. Memórias vivas e a polonidade no município de Guarani das Missões/ RS. Dissertação de Mestrado. Programa de Pós-Graduação em Geociências. Universidade Federal do Rio Grande do Sul, UFRGS. 2013

TARALlO, F. A pesquisa sociolinguística. São Paulo: Ática, 1990.

TOMACHESKI, M. B. A terra prometida da Virgem Maria: imigrantes, viajantes intelectuais e colonos na imigração polaca. 2014. 264 f. Dissertação (Mestrado em História) - Universidade do Vale do Rio dos Sinos, São Leopoldo, 2014. Disponível em: http:// biblioteca.asav.org.br/vinculos/00000b/00000b9a.pdf Acesso em: 21 jan. 2017.

WACHOWICZ, R. C. História do Paraná. Ponta Grossa: Editora UEPG, 2010.

WACHOWICZ, R. C. O camponês polonês no Brasil. Curitiba: Fundação Cultural; Casa Romário Martins, 1981.

WACHOWICZ, R. C.; MALCZEWSKI, Z. Perfis polônicos no Brasil. Curitiba: Vicentina, 2000.

WOLNY, A. A polaca - a mulata ao avesso? Romanica Cracoviensia. Universidade Jagellónica de Cracóvia, vol. 12, 2012, p. 338-348. Disponível em: http://cejsh.icm. edu.pl/cejsh/element/bwmeta1.element.desklight-c35dafc7-03ea-4d58-8760-345aad2685a4 Acesso em 20 jan. 2017.

Data de submissão: 28/02/2017

Data de aceite: $31 / 03 / 2017$ 